\title{
CEREAIS DE INVERNO SUBMETIDOS AO CORTE NO SISTEMA DE DUPLO PROPÓSITO
}

\author{
WINTER CEREALS SUBMITED TO CUTTINGS UNDER CONDITIONS \\ OF DOUBLE PURPOSE SYSTEM
}

\author{
Patricia Cambrussi BORTOLINI \\ Orientador: Professor Dr. Paulo Cesar de Faccio CARVALHO (Departamento de Forrageiras - UFRGS)
}

\begin{abstract}
RESUMO
Objetivou-se, nos dois experimentos realizados, avaliar o potencial de utilização para forragem e grãos de aveia branca (Avena sativa L.), trigo (Triticum aestivum), triticale (X. Triticosecale Witt.), aveia preta (Avena strigosa Schreb), centeio (Secale cereale L.) e cevada (Hordeum vulgare L.), visando uma utilização em condições de duplo propósito. O primeiro experimento foi realizado de abril de 1994 a setembro de 1996 e o segundo de abril de 1995 a dezembro de 1997 em Guarapuava, Paraná. Utilizou-se o delineamento experimental de blocos ao acaso, com tratamentos distribuídos em parcelas subdivididas, em três repetições. As parcelas foram os sistemas de produção (sem corte, um e dois cortes) e as sub-parcelas, os genótipos. No primeiro experimento, o sistema dois cortes foi superior aos demais quanto ao rendimento de matéria seca, principalmente para a aveia. Para o rendimento de grãos, os sistemas sem corte e um corte foram superiores,

apesar da maior produção dos genótipos de aveia sob dois cortes. Em todos os genótipos houve melhoria do peso do hectolitro e redução da massa de mil sementes quando realizou-se cortes. A margem bruta, na média dos genótipos, foi superior no sistema um corte. No segundo experimento ocorreu maior produção de matéria seca com dois cortes. Genótipos não cortados obtiveram produção de grãos superior aos demais. O peso do hectolítro dos genótipos de trigo foi superior aos demais quando sem corte e com um corte. O sistema sem corte apresentou maior valor para massa de mil sementes. Ocorreu redução na altura das plantas quando submetidas a um e dois cortes e genótipos submetidos ao sistema sem corte apresentaram maior acamamento. Sob condições de manejo adequadas, pode-se alcançar considerável produção de forragem sem afetar a posterior produção de grãos para cereais de inverno.
\end{abstract}

ABSTRACT

The objective in the two accomplished experiments, was to evaluate the use potential for forage and grains of white oat, wheat, triticale, black oat, rye and barley, seeking an use in conditions of double purpose. The first experiment was accomplished of April of 1994 to September of 1996 and the second of April of 1995 to December of 1997 in Guarapuava, Paraná. The experimental design was a randomized complet blocks, with treatments distributed in subdivided portions, in three replications. The plots were the production systems (without cul, one and two cut) and the sub-plot, the genotypes. In the first experiment, the system two cut went superior to the others with relationship to the dry matter, mainly for the oat. For the grains yield, the systems without cut and one cut were superior, in spite of the largest production of the genotype of oat under two cut.
In all the genotypes there were improvement of the weight of the hectoliter and reduction of the mass of a thousand seeds when cuts were done. In the second experiment in happened larger production of dry matter with two cuts. Non cut Genotypes obtained superior production of grains to the olhers. The weight of the hectoliter of the wheat genotypes went superior to the others when without cut and with one cut. The system without cut presented larger value for mass of a thousand seeds. It happened reduction in the height of the plants when submitted to one and two and genotypes submitted to the system without cut presented larger drooping. Under appropriate handling conditions, it can be reached considerable forage production without affecting the posterior production of grains for winter cereals. 